\title{
GAS1 wt Allele
}

National Cancer Institute

\section{Source}

National Cancer Institute. GAS1 wt Allele. NCI Thesaurus. Code C106452.

Human GAS1 wild-type allele is located within 9q21.3-q22 and is approximately $3 \mathrm{~kb}$ in length. This allele, which encodes growth arrest-specific protein 1 , is involved in cell growth suppression through cell cycle arrest. Mutations in this gene play a role in holoprosencephaly. 